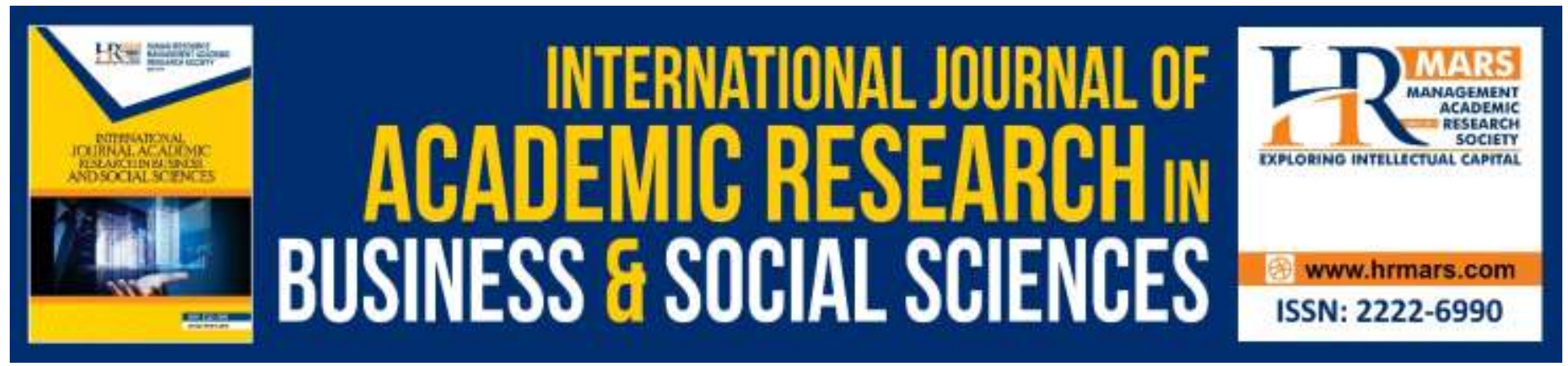

\title{
Determinants of Foreign Direct Investment Outflow of Malaysia: Vector Error Correction Model
}

\section{Yong Jhen Kai, Jerome Kueh, Yong Sze Wei, Josephine Yau, Audrey Liwan}

To Link this Article: http://dx.doi.org/10.6007/IJARBSS/v9-i11/6538

DOI: $10.6007 /$ IJARBSS/v9-i11/6538

Received: 15 July 2019, Revised: 10 August 2019, Accepted: 30 August 2019

Published Online: 24 Oct 2019

In-Text Citation: (Kai et al, 2019)

To Cite this Article: Kai, Y. J., Kueh, J., Wei, Y. S., Yau, J., Liwan, A. (2019). Determinants of Foreign Direct Investment Outflow of Malaysia: Vector Error Correction Model. International Journal of Academic Research in Business and Social Sciences, 9(11), 144-158.

Copyright: (C) 2019 The Author(s)

Published by Human Resource Management Academic Research Society (www.hrmars.com)

This article is published under the Creative Commons Attribution (CC BY 4.0) license. Anyone may reproduce, distribute, translate and create derivative works of this article (for both commercial and non-commercial purposes), subject to full attribution to the original publication and authors. The full terms of this license may be seen at: $\underline{\text { http://creativecommons.org/licences/by/4.0/legalcode }}$

Vol. 9, No. 11, 2019, Pg. 144 - 158

Full Terms \& Conditions of access and use can be found at http://hrmars.com/index.php/pages/detail/publication-ethics 


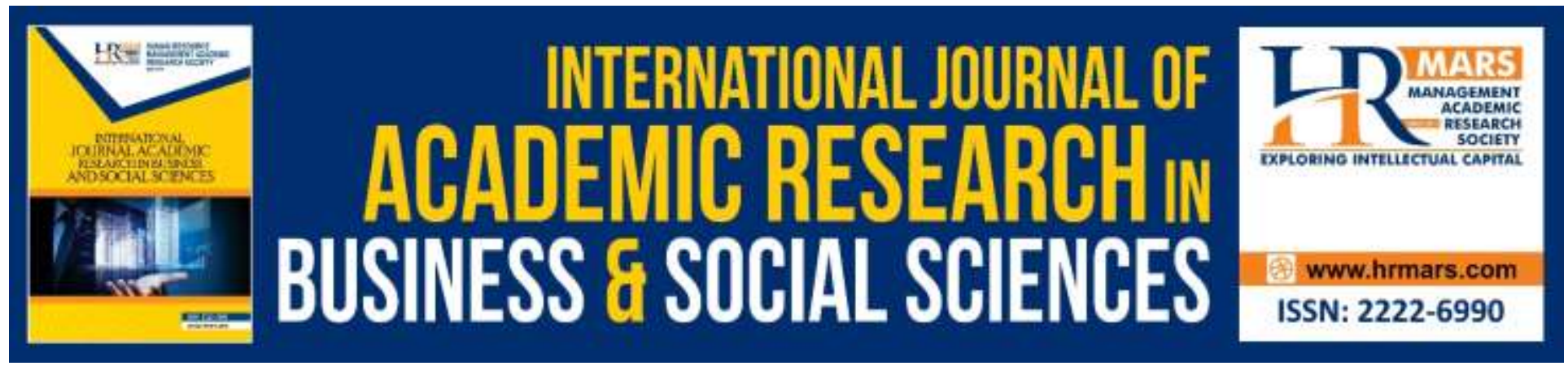

\title{
Determinants of Foreign Direct Investment Outflow of Malaysia: Vector Error Correction Model
}

\author{
Yong Jhen Kai ${ }^{1}$, Jerome Kueh ${ }^{2 *}$, Yong Sze Wei ${ }^{3}$, Josephine Yau \\ Audrey Liwan ${ }^{5}$
}

1,2,4,5 Faculty of Economic and Business, Universiti Malaysia Sarawak, 94300 Kota Samarahan, Sarawak, Malaysia, ${ }^{3}$ Faculty of Business and Management, Universiti Teknologi MARA, 94300

Kota Samarahan, Sarawak, Malaysia, * Jerome Kueh, Faculty of Economics and Business, Universiti Malaysia Sarawak, 94300 Kota Samarahan, Sarawak, Malaysia.

Email: kshjerome@unimas.my

\begin{abstract}
This study aims to investigate the determinants of outwards FDI of Malaysia. This study adopted annually data of outwards FDI, market size, trade openness, technology level, and exchange rates which ranging from 1986 to 2016. Augmented Dickey-Fuller (ADF) unit root test, Johansen and Juselius cointegration test and Vector Error Correction Model (VECM) are employed to determine the relationship between the outward FDI and its determinants. The results of unit root tests show that all the variables were stationary after first difference, /(1). Besides that, the cointegration results imply a stable long run equilibrium exist between variables. Based on VECM results, the outwards FDI is affected by all the explanatory variables in both short run and long run. The results obtained are beneficial for the government and policy makers to implement and enhance the outwards FDI in Malaysia.
\end{abstract}

Keywords: Outwards FDI, Vector Error Correction Model, Trade Openness, Technology Level, Exchange Rate.

\section{Introduction}

Foreign direct investment (FDI) has been considered as an important element in developing the countries' national development throughout the world. However, role of inward flow is more focused compared to outward flows based on the traditional strategies. Outwards foreign direct investment has been getting more important during the last decades, playing an important role for the world economy. Most of the FDI are still coming from the developed country and go to different developing countries. However, during the last few decades outwards FDI are getting more favourable and starting to draw for the attention of the researchers. The outward direct 
investment's growing level has generated featured results, as the Malaysian firms that invested overseas gained better profits and dividends, especially after year 2002.

FDI outflow is important in expanding existing market in Malaysia companies and if the interest rate in a foreign country is low as compared to India there would be greater incentive to borrow abroad and make direct investments abroad. Somehow, the small domestic market size caused more pressure for the firms to go global. Externally, the globalization's competitive pressures as well as the liberalization of other emerging economies such as Cambodia, Laos and Vietnam further contribute more fuel toward global markets as they earn more profits and experience economic growth. Besides that, Malaysia government supported outward FDI in four main forms which are (1) tax free, tax incentives and special funds, (2) investment guarantee agreements, (3) trade and investment missions and (4) institutional support. In the previous studies by different researchers, they had proved that market size of the host country can affect the FDI outflows of that country. According to the market size analysis, a large market always brings higher profit if compared to the small market (Buckley et al., 2007). Besides that, from a point of firm's view, a large market size is important in utilizing resources efficiently and exploitation of economies of scale (Scarperlanda \& Mauer, 1973). When the gross domestic product increases, the firm can be more easily to develop specific ownership advantage relative international corporations. This can bring internalisation advantages as it can make the firms more profitable in exploiting their ownership advantages (Dunning, 1981a), especially knowledge related to intangible assets (Buckley, 2014). Besides that, previous researchers that studied about Malaysia's OFDI have found that an increase in trade openness of host country was eventually encouraging OFDI (Kueh, et al., 2009). Not only that, Kohlhagen (1977) studied that firms from countries with stronger currency have greater financial advantages compared to firms from countries with lower currency when financing or acquiring foreign operations. Home currency appreciation can decrease the nominal competitiveness of exports and increases the wish of domestic farms to invest overseas (Krykilis \& Pantelidis, 2003). There are many variables are being used in the previous studies to determine how OFDI is being affected. Therefore, it is essential to examine the determinants that contribute in Malaysia OFDI which has fluctuated flows in the recent years.

This study is generally aimed to investigate the pattern of OFDI in Malaysia while the specific objectives is to identify the determinants that affected outward foreign direct investment (OFDI) in Malaysia and to study whether the market size, trade openness, technology level and exchange rate has a potential to influence OFDI in Malaysia. Most of the studies rely to foreign direct investment are primarily focused on FDI inflows into Malaysia. A lot of attention by both media and academician has been focused on FDI inflows. If we focused on emerging economies like Malaysia which experience a massive growth in the past and this can encourage Malaysia companies to venture in the foreign countries for accessing the technology, access to resources. Companies can also enter foreign economies to adopt existing intellectual property which provides them a competitive advantage over current competitors. Besides that, this study includes the level of technology component in the model to better capture the determinants of OFDI. Technology aspect also plays an important role in the outward FDI and emerging countries 
are catching up on technology progress. Hence, this study is important to understand the change of the foreign direct investment's flow and to bridge the research gap between inwards FDI and outwards FDI.

\section{Literature Review \\ Conceptual Framework}

Based on the previous study done by previous researchers, internalization theory was used to explain the multinational corporate growth (MNE) and becoming one of foreign direct investment reasons. Dunning and Gugler (2008) offered a framework that known as eclectic theory or OLI theory, with $O$ stands for ownership, $L$ stands for locational advantages and $/$ stands for internalization. Accordingly, companies undertake FDI when they have ownership (O) advantages (number of patents), which they take advantage through the internalization (I) process in other countries that provide the required locational $(L)$ advantages. This idea has come into central paradigm during 1980's and 1990's. Somehow, there is several difficulties in the explanatory capacity of OLI theory for multinational firms from developing countries and hence it needed to be adopted (Saad et al., 2014).

"Investment development path" (IDP) hypothesis recommended by Dunning claimed that a country's income level is positively related to the level of outward FDI. Not only that, Sermcheep mentioned that the change in the FDI pattern could be justified by the stages theory of competitive development promoted by Porter (1990). According to IDP, the direction of inwards and outwards FDI are influenced by the changes in the home macroeconomic environment as the economy develops. In this context, five stages of economic development will be undergoing by a country depending to their scheme of inward and outward investment. In stage one, only a little of inwards and outwards FDI in the least developed countries. There will be increasing inwards FDI into the country in stage two but the outwards FDI remains negligible. In stage three, growth rate of inwards FDI started to decline while the outwards FDI will start to increase in a rapid rate. In stage four, outwards FDI will boost up to a state of exceeding or equivalent to the inwards FDI. In last stage, the net FDI status fluctuate near to zero, pointing that inwards and outwards FDI are likely to move at a same rate. As a result, a country will develop from the role as a net FDI recipient to a net FDI contributor, possessing to the competitive advantages of firms that are becoming better along these routes. Hence, it can transform a nation from "the least developed" to "developed" economy.

\section{Empirical Reviews}

According to Charlotte and Karin (2015), when the gross domestic product of a country increases, the ability of national firms to launch specific ownership advantages relative international corporations will also increase. In year 2007, OFDI started to play an important role compared to IFDI in Malaysia as the amount of OFDI (11,314\$ million) is greater than the amount of IFDI $(8,595 \$$ million). Foreign direct investments either inflow or outflow, both are actually good for a country's economy (Saad, Noor \& Nor, 2014). Liu and Pitprapha (2017) stated that market size, the openness of Thailand, the relative real wage, the relative intensity of $R \& G$, bilateral trade 
agreements have positive and statistically significant effects on Thailand's external FDI. In developed countries, FDI may also be motivated by avoiding high public contributions or uncertainty about the local financial system (Arthur, 2013). In the early 1970's and early 1980's, Scaperlanda and Mauer (1973) and Scaperlanda and Balough (1983) have investigated the relationship between FDI and economic openness and they concluded that by liberalizaing of a country's foreign business dealing, it allows limitless funds for overseas investment that have a positive impact on FDI outflows.

Meanwhile, Kueh et al., (2008) stated that openness of the country was positively affected the outward FDI in Malaysia. Somehow, if that country is an export-orientated economy, the firms have easier access to knowledge about foreign markets. Therefore, they have better skills in arranging foreign tasks, and how to promote their products internationally. Due to this a firm may modifies their plan in order to serve the international market from export to FDI. Besides that, the ownership of technology gives extra advantage for the firm compared to other firms, and the best method to preserve the knowledge is by internalization. At the same time, the incentives for direct foreign investment also increased (Kyrkilis \& Pantelidis, 2003). For patent system, politics, market structure as well as laws and regulation are different across countries. Not only that, the capability to find suitable competence and production elements seems to be differ, which conversely will influence the level of outwards FDI (Kyrkilis \& Pantelidis, 2003). Malaysian companies capable of moving up the value chain or launching integrated supply chain management by gaining interest in or forming partnerships with foreign companies. Most of the time, physical assets such as manufacturing equipment, high-tech and management expertise, brands and trademark rights were involved in established products (BNM, 2006). When Thailand firms searching for countries to invest, the main concern is the strength of currency (exchange rate) as a proxy for the inflation's level and the power to purchase of the investing firm (Liu \& Pitprapha, 2017). As the host country's currency increases in value, the investors are less likely to invest as their purchasing power in foreign currency terms is weakened (Chakrabarti, 2001). Saad et al., (2014) stated that exchange rate is estimated to positively affect the outward FDI.

\section{Methodology}

\section{Data Description}

For all the data used for the variable are obtained in the period of 31 years which started from year 1986 to year 2016. The data is not restricted therefore no problems faced while searching for the data in the given time period. In present study, GDP and GDP per capita income of host country always been adopted as appropriate proxy variables to measure market size. In some studies, GNP and per capita GNP also been adopted as a proxy for market size but the result gained is either overestimated or underestimated. GDP and GDP per capita is expected to be positively related to Malaysia's FDI outflows. Hence, GDP is used as the most suitable proxy variable for this study. The data for GDP is obtained from the World Bank Data and it is measured in million US dollars. The variable that will be used to determine the trade openness is openness index. It is measured as the ratio of country's total trade which is total of exports and imports, to the country's gross domestic product. Openness index can be interpreted as the higher the index, 
the larger the effect of trade on domestic activities. The data for trade openness is calculated manually after we managed to get the data for imports, exports and GDP from UNCTAD in year 1986- 2016. Technology level is not widely used by the researchers in the previous studies. By counting domestic and foreign citizens, number of patents granted in Malaysia is used as the proxy for the technology level. The data for number of patents granted in Malaysia is obtained from World Intellectual Property Organization (WIPO). Real effective exchange was adopted for the exchange rate variable, which is an index that calculates a currency's value against the basket of other currencies, divided by a price reflector. For this index, 2010 is used as the base year, as a proxy for the country's strong currency.

\section{Econometric Approach}

The research design and methodology will be discussed in greater detail and appropriate methods for collecting empirical information will be summarized. Not only that, research will be done on the reliability and validity of the study. Regression analysis model is used in this study where all the variables are tested independently within the selected period which is from 1986 to 2016 .

To estimate the relationships among variables, a statistical technique known as regression analysis is used. Ali (2015), Marco (2012) used the multiple regression analysis with other variables in discussing their researches. The following are variables that mostly used by the previous researchers. The equation could be expressed as below:

$$
\log (O F D I)=\alpha_{0}+\beta_{1} \log (G D P)+\beta_{2} \log (O P E N)+\beta_{3} \log (P A T)+\beta_{4} \log (E R)+\varepsilon_{\tau}
$$

where OFDI represents outwards foreign direct investment, $\alpha$ is a constant term, GDP, gross domestic product, as a proxy representing market size, OPEN represents openness of trade, PAT, number of patent grants as proxy for level of technology, ER represents real effective exchange rate and $\varepsilon_{\tau}$ represents stochastic term.

Based on the model above, foreign direct investment is affected by independent variables that are gross domestic product, trade openness, number of patent grants and real effective exchange rate. In this model, gross domestic product is a crucial determinant in deciding outward FDI of a country. Level of GDP stands for OLI theory's ownership advantage and high correlation is expected to hold between the size of the internal market and investment overseas (Kalotay \& Sulstarova, 2010). The want to develop, widen markets and promote channels of trade and distribution were the main drivers of the outward FDI of the most little developed countries. The level of GDP is used as a proxy for the size of the domestic market and a positive relationship between external FDI is expected.

Trade openness measures economic policies that either restrict or invite trade between countries. It is used to explore correlation between outwards FDI and openness to trade. The formula of trade openness (OPEN) is written as below: 


$$
\frac{\text { Export }+\operatorname{Import}(X+M)}{\text { Gross Domestic Product }}=\frac{N X}{G D P}
$$

As the formula shown, trade openness is calculated as the summation of exports and imports divided by the GDP. Foreign production can change exports of a product but usually boosts demand for intermediate products or raw materials from the home country (Sermcheep, 2013). $\mathrm{Ng}$ (2010) stated movement of trades are significantly and positively correlated with the movement of investments, and its predicted that trade openness will have positive impact on FDI outflows.

Besides that, number of patent grants is one of the crucial stimulating motions for FDI from companies in developing countries in order to compensate their competitive disadvantages regarding proprietary technology, management expertise and product bands while competing with multinational companies from developed countries (Child \& Rodrigues, 2005). Developing countries can increase the value chain or develop integrated supply chain management by becoming involved in or forming joint ventures with foreign partners. Patent registrations is used as proxy for level of technology. In the home country, if the level of technology is low, companies will be pushed to invest outside particularly in the developed countries to obtain higher technology. Outwards FDI is expected to have positive relationship with the number of patent grants in the home country. Furthermore, exchange rate is playing an important role in affecting outwards FDI. It can be rationalized that companies from countries with strong currencies tend to have financial advantages when compared with companies from countries with weak currencies when it comes to financing or acquiring foreign operations (Kohlhagen, 1997). Not only that, Kyrkillis and Pantelidis (2003) pointed out that depreciation of home currency tends to increase nominal export competitiveness and decrease the willingness of local companies to invest overseas to serve the overseas market Therefore, an exchange rate appreciation is assumed to have a positive impact on FDI from the outside. In overall, this model adopting five variables that consists of one dependent variable and four independent variables that shows the relationship of how the coefficient of those independent variables affects the dependent variable, outwards FDI.

After that, Augmented Dickey- Fuller (ADF) unit root test was applied to find out whether the data from the time series is stationary or non-stationary. The more negative of the ADF statistic, the stronger the rejection of hypothesis that there is a unit root at $90 \%, 95 \%$ or $99 \%$ level of confidence or $10 \%, 5 \%$ or $1 \%$ level of significance. The unit root test is conducted with null hypothesis $\beta_{i}=0$ against the alternative hypothesis of $\beta_{i}<0$. The cointegration test of Johansen is mostly applied to study the long-term relationship and movement between all variables. To carry out the cointegration test of Johansen and Juselius, the VAR model must be formulated as follows:

$$
\Delta y_{t}=\tau_{1}(1) \Delta y_{t-1}+\tau_{2}(1) \Delta y_{t-1}+\cdots+\tau_{n}(1) \Delta y_{t-1}+\varepsilon_{\tau}
$$


From equation above, $\Delta y_{t}$ means the first difference operator of column vector and $\tau_{n}(1)$ with $\mathrm{k}=1 \ldots, \mathrm{n}$ be a lag operator. $\varepsilon$ is the residual white noise of zero mean and contract variance. The model order selection must be determined by applying the Information Criterion (AIC) of Akaike in advance. There are two test statistics that mostly applied in the Johansen and Juselius test which are trace and maximum eigenvalue as stated as below:

$$
\boldsymbol{\tau}_{\text {trace }}=-N \sum_{i=r+1}^{m} \ln \left[1-\left(\boldsymbol{r}_{\boldsymbol{i}} *\right)^{2}\right]
$$

The equation above shows that trace test regression where $\mathrm{N}$ represents the total quantity of observations, $\mathrm{M}$ is the total quantity of variables, $\boldsymbol{r}_{\boldsymbol{i}} *$ denotes i correlation between variables of the $\mathrm{i}$-th pair. There is a chi-square distribution with M-r freedom.

$$
\tau_{\max }=-T \ln \left(1-\lambda_{r+1}\right)
$$

Johansen and Juselius (1990) said the maximum test of its own value holds more power than trace test by demonstrating the more robust result in the maximum eigenvalue test and the equation was stated in equation above where $T$ is the total amount of observation and $\lambda_{r+1}$ stands for the largest estimated eigenvalue. Overall, the hypotheses of trace test and maximal eigenvalue are about the same and were explained as follows:

$H_{o}: r=r_{o}$ (no cointegration)

$H_{1}: r=r_{o}+1$ (cointegration exist)

The null hypothesis indicates that no co integrating vector is found while the alternative hypothesis says that one or more co integrating vector is found. The rejection of null hypothesis means that there is an existence of long run linkage in the model. After presence of any co integrating vector in the Johansen co integration test, to investigate the dynamic relationship between variables, an appropriate VAR system consists of ECT is needed. The Vector Error Correction Modelling (VECM) could provide a framework for learning the short-term, long-term causal relationship and causal effects among variables using Granger causality on a VECM basis. The estimation of standard VAR is employed when the variables are non-stationary and not co integrated. In contrast, the model with non-stationary and co integrated variables, estimation of VECM is used to examine the existence of long run linage between the determinants and the outwards FDI. This analysis used to prevent the issues of misspecification (Baharumslah \& Lau, 2007).

\section{Results}

Firstly, Augmented Dickey- Fuller (ADF) test was applied to find out whether the data from the time series is stationary or non-stationary. The results of unit root test are shown in Table 1. Empirical results indicated that at both constant and with trend condition at level, the null hypothesis cannot be rejected. Hence, the time series data consists of unit root and the variables are non- stationary at level. After that at both constant and with trend condition at first difference, we rejected the null hypothesis as the value of $t_{\text {statistics }}$ is greater than $t_{\text {critical }}$. It can show that the variables are stationary at $5 \%$ and $1 \%$ significant levels respectively in $1^{\text {st }}$ 
INTERNATIONAL JOURNAL OF ACADEMIC RESEARCH IN BUSINESS AND SOCIAL SCIENCES

Vol. 9, No. 11, November, 2019, E-ISSN: 2222-6990 @ 2019 HRMARS

difference. As a result, the OFDI, GDP, REER, TL and OPEN are demonstrated to be integrated to first order since they become stationary after being differenced.

Table 1: ADF unit root test results

\begin{tabular}{c|cccc}
\hline \multicolumn{1}{l}{ Variables } & \multicolumn{2}{c}{ Without Trend } & \multicolumn{2}{c}{ With Trend } \\
\hline & Level & First difference & Level & First difference \\
OFDI & $-1.3488(0)$ & $-5.9657(0) * * *$ & $-2.1299(0)$ & $-5.8594(0) * * *$ \\
GDP & $-0.0028(0)$ & $-4.8749(0) * * *$ & $-1.7086(0)$ & $-4.8335(0) * * *$ \\
REER & $-2.5016(0)$ & $-4.5210(0) * * *$ & $-2.8607(0)$ & $-4.4823(0) * * *$ \\
TL & $-2.2969(0)$ & $-6.0162(0) * * *$ & $-2.9798(0)$ & $-5.9103(0) * * *$ \\
OPEN & $-1.5649(0)$ & $-4.1334(0) * * *$ & $-1.1536(0)$ & $-5.4486(0) * * *$ \\
\hline
\end{tabular}

Notes: Asterisks $\left({ }^{* *}\right),\left({ }^{* *}\right),\left({ }^{*}\right)$ denote significant at $1 \%, 5 \%$ and $10 \%$ level, respectively. Figures in parentheses are the lag lengths.

We can therefore conclude that all variables have the same integration order. In the next step, cointegration test was used to find out the existence of a long-term relationship between all the variables integrated in the same order. The cointegration test of Johansen is mostly applied to study the long-term relationship and movement between all variables. Engle and Granger (1987) mentioned that for cointegration test only variables at the same level of integration can be used. The results obtained are shown in Table 2. From Table 2, trace test results show that the null hypothesis of $r=0$ is rejected at $5 \%$ level of significance. The computed value 85.5482 is larger than 69.819. After that, the result showed that the null hypothesis of $r \leq 1$ is rejected at $5 \%$ significant level as the computed value 51.1336 is greater than 47.8561 . At the same time, it is concluded that there is an existence of two cointegrating vector in the model between the variables. The Maximum Eigenvalue test gives distinct results as compared to trace test in Table 2. In Maximum Eigenvalue test, the null hypothesis of $r=0$ is rejected at $5 \%$ level of significance. The computed value 34.4146 is less than 33.877. Meanwhile, it is concluded that there is one cointegrating vector in the model between the variables.

Table 2: Johansen and Juselius Cointegrating Test Result

\begin{tabular}{llcc}
\hline $\mathrm{H}_{0}$ & $\mathrm{H}_{1}$ & $\begin{array}{c}\text { Max-Eigen } \\
(\lambda \text { max })\end{array}$ & $\begin{array}{c}\text { Trace } \\
(\lambda \text { trace })\end{array}$ \\
\hline
\end{tabular}

\begin{tabular}{|c|c|c|c|c|c|}
\hline \multicolumn{6}{|c|}{ Variables: OFDI, GDP, REER, TL, OPEN } \\
\hline$r=0$ & $r=1$ & $34.4146 * *$ & 33.8769 & $85.5482 * *$ & $69.8189 * *$ \\
\hline$r \leq 1$ & $r=2$ & 24.3941 & 27.5843 & $51.1336 * *$ & $47.8561 * *$ \\
\hline$r \leq 2$ & $r=3$ & 15.0913 & 21.1316 & 26.7395 & 29.7971 \\
\hline$r \leq 3$ & $r=4$ & 11.5265 & 14.2646 & 11.6482 & 15.4947 \\
\hline
\end{tabular}

Notes: $r$ indicates the number of cointegrating vectors. Asterisks $\left({ }^{* *}\right)$ indicate statistically significant at $5 \%$ significant level. The report statistics of maximum eigen value and trace test have not been adjusted for small sample size. 
Because both the results for trace and max-eigen test are different, max eigenvalue result is chosen as it holds more power than trace statistics. Moreover, Johansen and Juselius (1990) also recommend using max eigenvalue statistics when both the statistics provided conflicting results. Hence, we can conclude that outwards foreign direct investment and its determinants are exhibiting a stable long run relationship. It also means that they are causally related or cointegrated in at least one direction. A cointegrating vector was found in the cointegration test. Cointegration detection suggests that there is an appropriate VAR system (ECT) and the dynamic relationship between variables needs to be examined. Table 3 explains the findings of the Granger causality test in VECM framework and Error Correction Term (ECT)

Table 3: Granger Causality Test Results

\begin{tabular}{|c|c|c|c|c|c|c|c|}
\hline \multirow{2}{*}{$\begin{array}{l}\text { Depende } \\
\text { nt } \\
\text { variable }\end{array}$} & $\triangle O F D I$ & $\Delta G D P$ & $\triangle R E E R$ & $\Delta T L$ & $\triangle O P E N$ & EC & \\
\hline & \multicolumn{5}{|c|}{$x^{2}$-statistics } & $\begin{array}{c}\text { Coefficie } \\
\text { nt }\end{array}$ & $\begin{array}{c}t- \\
\text { ratio }\end{array}$ \\
\hline$\triangle \mathrm{OFDI}$ & - & $\begin{array}{c}10.08(0.01) \\
* *\end{array}$ & $\begin{array}{c}5.79(0.0 \\
6)\end{array}$ & $\begin{array}{c}0.26(0.8 \\
8)\end{array}$ & $\begin{array}{c}4.66(0.0 \\
9)\end{array}$ & 0.8985 & $\begin{array}{c}2.980 \\
5\end{array}$ \\
\hline$\triangle \mathrm{GDP}$ & $\begin{array}{c}15.37(0.00) \\
* *\end{array}$ & - & $\begin{array}{c}4.73(0.0 \\
9)\end{array}$ & $\begin{array}{c}0.11(0.9 \\
4)\end{array}$ & $\begin{array}{c}4.83(0.0 \\
9)\end{array}$ & 8.8313 & $\begin{array}{c}3.363 \\
7\end{array}$ \\
\hline$\triangle \mathrm{REER}$ & $2.64(0.27)$ & $0.31(0.86)$ & - & $\begin{array}{c}0.48(0.7 \\
9)\end{array}$ & $\begin{array}{c}0.45(0.7 \\
9)\end{array}$ & 0.0027 & $\begin{array}{c}3.029 \\
8\end{array}$ \\
\hline$\Delta T L$ & $\begin{array}{c}25.41(0.00) \\
* *\end{array}$ & $\begin{array}{c}7.89(0.02)^{*} \\
*\end{array}$ & $\begin{array}{c}0.57(0.7 \\
5)\end{array}$ & - & $\begin{array}{c}2.38(0.3 \\
0)\end{array}$ & 0.3857 & $\begin{array}{c}- \\
1.550 \\
4\end{array}$ \\
\hline$\triangle \mathrm{OPEN}$ & $1.63(0.44)$ & $0.72(0.69)$ & $\begin{array}{c}4.86(0.0 \\
9)\end{array}$ & $\begin{array}{c}0.09(0.9 \\
5)\end{array}$ & - & -0.0059 & $\begin{array}{c}- \\
2.950 \\
4\end{array}$ \\
\hline
\end{tabular}

Notes: Asterisks $\left({ }^{* *}\right)$ indicates $5 \%$ significance level.

Table 3 shows that there is a short run unidirectional Granger causality running from, OFDI to TL and GDP to TL. Besides that, bidirectional Granger causality was found between OFDI and GDP. Based on the results, the ECT coefficient of $\triangle O P E N$ carries the right sign that is negative, less than one and statistically significant at a level of $5 \%$ significant, proving that $\triangle O P E N$ is adjusted to the long-term level of equilibrium. It means that there is a long-term relationship between the variables corresponding to the cointegration test of Johansen and Juselius. This value suggests that the only way to bring $\triangle O P E N$ about the long-term equilibrium in Malaysia is to bear the short-term adjustment. Besides that, all the variables are affecting $\triangle O P E N$ in the long run because the ECT coefficient of $\triangle O P E N$ is carrying the right sign. This implies that $\triangle O F D I, \triangle G D P, \triangle R E E R$ and $\triangle T L$ affect $\triangle O P E N$ in long run before $\triangle O P E N$ backs to equilibrium. Approximately 0.0059 of the short run deviations will be adjusted annually to the equilibrium, or it indicates that approximately 0.59 percent of the adjustment occurs annually. In addition, it is concluded that that the adjustment's speed is around 169 years and 6 months to back to equilibrium. 
Figure 3: Short run Causality Direction

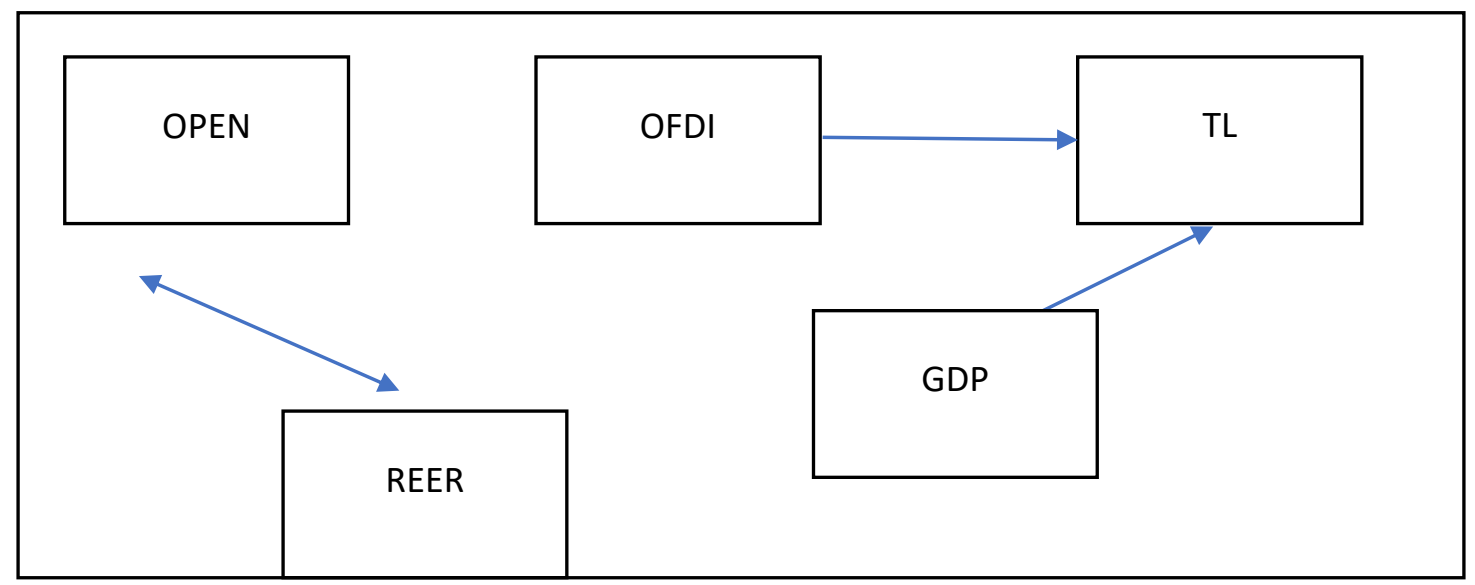

Table 4: Results of Variance Decomposition

\begin{tabular}{|c|c|c|c|c|c|c|c|}
\hline \multirow{2}{*}{$\begin{array}{l}\text { Percent } \\
\text { age of } \\
\text { variatio } \\
\text { ns in }\end{array}$} & \multirow{2}{*}{$\begin{array}{c}\text { Horizon } \\
\text { (Quarter } \\
\text { s) }\end{array}$} & \multicolumn{6}{|c|}{ due to innovation in: } \\
\hline & & $\triangle O F D I$ & $\Delta$ GDP & $\triangle$ REER & $\Delta \mathrm{TL}$ & $\triangle O P E N$ & $\Delta \mathrm{CU}$ \\
\hline \multicolumn{8}{|c|}{ Quarters Relative Variance in: $\triangle$ OFDI } \\
\hline & 1 & 100 & 0.0000 & 0.0000 & 0.0000 & 0.0000 & 100 \\
\hline & 10 & 41.4292 & 1.3097 & 0.7136 & 56.3263 & 0.2212 & 58.5708 \\
\hline & 20 & 41.9727 & 1.1426 & 0.6937 & 55.9784 & 0.2158 & 58.0273 \\
\hline & 30 & 42.2729 & 1.0599 & & 55.7690 & 0.2175 & 57.7271 \\
\hline & & & & 0.6807 & & & \\
\hline & 40 & 42.4207 & 1.0185 & 0.6740 & 55.6672 & 0.2196 & 57.5793 \\
\hline & 50 & 42.5095 & 0.9936 & 0.6700 & 55.6060 & 0.2209 & 57.4905 \\
\hline \multicolumn{8}{|c|}{ Quarters Relative Variance in: $\Delta$ GDP } \\
\hline & 1 & 56.2624 & 43.737 & 0.0000 & 0.0000 & 0.0000 & 56.2624 \\
\hline & & & 6 & & & & \\
\hline & 10 & 32.0865 & 5.3542 & 0.1924 & 61.6210 & 0.7459 & 94.6458 \\
\hline & 20 & 31.3033 & 2.2246 & 0.1075 & 65.6510 & 0.7139 & 97.7754 \\
\hline & 30 & 31.2118 & 1.4185 & 0.0842 & 66.5976 & 0.6877 & 98.5815 \\
\hline & 40 & 31.1694 & 1.0435 & 0.0733 & 67.0380 & 0.6759 & 98.9565 \\
\hline & 50 & 31.1447 & 0.8266 & 0.0670 & 67.2927 & 0.6690 & 99.1734 \\
\hline \multicolumn{8}{|c|}{ Quarters Relative Variance in: $\triangle$ REER } \\
\hline & 1 & 0.2359 & 31.602 & 68.162 & 0.0000 & 0.0000 & 31.8380 \\
\hline & & & 1 & 0 & & & \\
\hline & 10 & 21.5842 & 7.6340 & 20.746 & 43.2127 & 6.8224 & 79.2534 \\
\hline & & & & 6 & & & \\
\hline & 20 & 23.7860 & 4.1839 & 19.353 & 44.2275 & 8.4490 & 80.6464 \\
\hline & & & & 6 & & & \\
\hline
\end{tabular}


INTERNATIONAL JOURNAL OF ACADEMIC RESEARCH IN BUSINESS AND SOCIAL SCIENCES

Vol. 9, No. 11, November, 2019, E-ISSN: 2222-6990 @ 2019 HRMARS

$\begin{array}{ccccccc}30 & 24.5189 & 3.1579 & \mathbf{1 9 . 0 2 8} & 44.0744 & 9.2208 & \mathbf{8 0 . 9 7 2 0} \\ & & & \mathbf{0} & & & \\ 40 & 24.8911 & 2.6336 & \mathbf{1 8 . 8 5 7} & 44.0120 & 9.6054 & \mathbf{8 1 . 1 4 2 1} \\ 50 & 25.1167 & 2.3159 & \begin{array}{c}\mathbf{1 8 . 7 5 4} \\ \mathbf{7}\end{array} & 43.9745 & 9.8383 & \mathbf{8 1 . 2 4 5 3}\end{array}$

Quarters Relative Variance in: $\Delta \mathrm{TL}$

\begin{tabular}{|c|c|c|c|c|c|c|}
\hline 1 & 0.8826 & 0.1218 & $\begin{array}{c}15.123 \\
3\end{array}$ & 83.8723 & 0.0000 & 16.1277 \\
\hline 10 & 19.3712 & $\begin{array}{c}33.393 \\
6\end{array}$ & $\begin{array}{c}11.720 \\
9\end{array}$ & 35.1058 & 0.4084 & 64.8942 \\
\hline 20 & 23.6249 & $\begin{array}{c}41.278 \\
4\end{array}$ & $\begin{array}{c}10.201 \\
6\end{array}$ & 24.0218 & 0.8733 & 75.9782 \\
\hline 30 & 24.9477 & $\begin{array}{c}43.712 \\
8\end{array}$ & 9.7387 & 20.5079 & 1.0928 & 79.4921 \\
\hline 40 & 25.6503 & $\begin{array}{c}45.002 \\
7\end{array}$ & 9.4952 & 18.6463 & 1.2056 & 81.3537 \\
\hline 50 & 26.0836 & $\begin{array}{c}45.798 \\
4\end{array}$ & 9.3449 & 17.4979 & 1.2752 & 82.5021 \\
\hline \multicolumn{7}{|c|}{ e Variance in: $\triangle O P E N$} \\
\hline 1 & 21.4734 & 5.0460 & $\begin{array}{c}39.213 \\
2\end{array}$ & 0.2102 & 34.0573 & 65.9427 \\
\hline 10 & 3.7122 & 3.5593 & 8.9607 & 66.6112 & 17.1566 & 82.8434 \\
\hline 20 & 3.2247 & 4.9452 & 7.0976 & 70.2911 & 14.4414 & 85.5586 \\
\hline 30 & 3.1168 & 5.2470 & 6.7373 & 71.0729 & 13.8260 & 86.1740 \\
\hline 40 & 3.0674 & 5.3774 & 6.5781 & 71.4199 & 13.5572 & 86.4428 \\
\hline 50 & 3.0395 & 5.4512 & 6.4880 & 71.6161 & 13.4052 & 86.5948 \\
\hline
\end{tabular}

For variable $\Delta \mathrm{OFDI}$, the $\Delta \mathrm{CU}$ is $57.49 \%$. Variable $\Delta \mathrm{TL}$ caused most impact towards variable $\Delta$ OFDI which is $55.60 \%$. After that, for variable $\Delta G D P$, the $\Delta C U$ is $99.17 \%$. Variable $\Delta T L$ caused most impacts towards variable $\Delta \mathrm{GDP}$ which is $67.29 \%$. For variable $\triangle \mathrm{REER}$, the $\Delta \mathrm{CU}$ is $81.24 \%$. Variable $\Delta T L$ caused most impacts towards variable $\triangle R E E R$ which is $43.97 \%$. For variable $\Delta T L$, the $\Delta C U$ is $82.50 \%$. Variable $\Delta$ GDP caused most impacts towards variable $\Delta T L$ which is $45.79 \%$. Lastly, for variable $\triangle \mathrm{OPEN}$, the $\triangle \mathrm{CU}$ is $86.59 \%$. Variable $\Delta \mathrm{TL}$ caused most impacts toward variable $\triangle \mathrm{OPEN}$ which is $71.61 \%$. Hence, we can conclude that variable $\Delta$ OFDI is the most exogenous variable with $\triangle \mathrm{CU}$ of $57.49 \%$ followed by variable $\triangle \mathrm{REER}$ with $\triangle \mathrm{CU}$ of $81.24 \%$, variable $\Delta \mathrm{TL}$ with $\Delta \mathrm{CU}$ of $82.50 \%$, variable $\triangle \mathrm{OPEN}$ with $\triangle \mathrm{CU}$ of $86.59 \%$ and lastly the most endogenous variable is $\Delta \mathrm{GDP}$ with $\Delta C U$ of $99.17 \%$. From results of variance decomposition, it is clear that $\Delta T L$ can cause most impacts towards variable $\triangle \mathrm{OFDI}$, variable $\triangle$ REER, variable $\triangle \mathrm{GDP}$ and variable $\triangle \mathrm{OPEN}$ in Malaysia. 


\section{Conclusion}

This study was done to investigate the impacts of chosen main determinants on outwards FDI in Malaysia. In ADF unit root test, the variables are found to be stationary at first difference which also called as I(1). After that, all the variables in the same order are subjected to Johansen and Juselius co integration test to make sure the existence of co integrating vectors among these variables in the long run equilibrium. The degree of freedom correlation adjustment was adopted into the maximum eigenvalue and trace statistics due to the relatively small sample in this study. Two co integrating vectors was detected in trace statistics while one co integrating vector was detected in adjusted maximum eigenvalue. Findings from max eigenvalue test statistics was adopted as max eigenvalue test statistics holds more power than the trace statistics. The model is satisfactory as it passed through all the diagnostic tests in the error correlation model. In the short run, outwards FDI and GDP influenced each other while both outwards FDI and GDP can influence the technology level in Malaysia. The estimation of ECT further confirmed that there existed a long run relationship between the variable trade openness and other variables. This also means that all other variables are affecting the variable trade openness in the long run. Based on the estimated coefficient of ECT, trade openness in Malaysia is predicted to takes around 169 years and 6 months to adjust back to the long run equilibrium. The results indicate that trade openness has positive impact on outwards FDI as proven by Hsiang and Pitprapha (2017) and Charlotte and Karin (2015). Besides that, technology has positive effect towards outwards FDI also been proven by Charlotte \& Karin (2015). GDP has positive relationship with OFDI as proven by Alma (2014), Anwar et al. (2016) and Arthur (2013). Lastly, real effective exchange rate also has positive relationship with OFDI. This is proven by Chen et al. (2016) and Kueh et al. (2008).

This study showed that the market size, trade openness, technology level and exchange rate are the main determinants to affect the outwards FDI in Malaysia. Therefore, more incentives should be given by the government for the operators to do outwards FDI to expand their market in Malaysia. The improvement in local business environment can stimulate the economic growth in Malaysia and hence boost up the outwards FDI in Malaysia. The second policy is related to the technology level in Malaysia which the technology level is closely related to the business environment and performance of firms in Malaysia. An increase in technology level means that the improvement of business environment in Malaysia which can strengthen the confident of investors. Number of patents, both by domestic and foreign-born residents is used as the proxy for technology level in this study as outwards FDI increases when number of patents increase. Hence, the government needs to be more focusing on the economic policies that foster the quality of the workforce. By doing this, the low-quality workers can adopt their cultures and become more professional in doing a specific profession. Improvement in policy regard to the trade liberalization would lead to high outwards FDI in Malaysia. As discussion from the findings, the trade openness contributes positive impacts towards outwards FDI through the improvement of productivity in Malaysia. Not only that, an expansion of Malaysia's trade activities enables the domestic firms to gain more knowledge on foreign markets. Hence, an orientated structural trade policy should be introduced in the country and therefore increase the amount of outwards FDI. 
The policy makers need to mend the barriers in the tariff system in order to promote the local firms to invest abroad and lift to economy integration level.

\section{References}

Anwar, I. A., Hasse, R., and Fazli. (2008). Location Determinants of Indian Outward Foreign Direct Investment: How Multinationals Choose their Investment Destinations? Retrieved from http://mpra.ub.uni-muenchen.de/47397/

Arthur, K. (2013). Institutions and outward foreign direct investment. Retrieved from https://www.etsg.org/ETSG2013/Papers/044.pdf

Buckley, P. J. and Casson, M. (1976). The Future of the Multinational Enterprise, London, MacMillan.

Buckley, P. J. (2002) 'Is the international business research agenda running out of steam?' Journal of International Business Studies 33(2): 365-373.

Buckley, P. J., and Lessard, D. (2005). Regaining the Edge for International Business Research. Journal of International Business Studies 36, 595-599.

Buckley, P. J., Clegg, J., Cross, A. R., Liu, X, Voss, H. and Zheng, P. (2007) "The determinants of Chinese Outward Foreign Direct Investment", Journal of International Business Studies, 38(4): 499-518.

Buckley, P. J. (2014). Forty Years of Internalisation Theory and the Multinational Enterprise. Multinational Business Review, 22(3), 227 - 245. Retrieved from http://dx.doi.org/10.1108/MBR-06-2014- 0022

Buckley, P. J. (2016). The Contribution of Internalization Theory to International Business: New Realities and Unanswered Questions. Journal of World Business, 51 (1). pp. 74-82. ISSN 1090-9516

Burke, S. P., \& Hunter, J. (2006). Modelling non-stationary economic time series: A multivariate approach. Basingstoke: Palgrave Macmillan.

Chakrabarti, A. (2001). The Determinants of Foreign Direct Investments: Sensitivity Analyses of Cross-Country Regression. Kyklos, 54(1), 89-114.

Charlotte, N. and Karin, H. (2015). Macroeconomic Determinants of European FDI Outflows: An Empirical Approach. Retrieved from https://gupea.ub.gu.se/bitstream/2077/40588/1/gupea_2077_40588_1.pdf

Culem, C. G. (1988), "The Locational Determinants of Direct Investment among Industrialized Countries."European Economic Review, 32, pp. 885-904.

Denisia, V. (2010). Foreign Direct Investment Theories: An Overview of the Main FDI Theories. European Journal of Interdisciplinary Studies, 2(2), 104-110.

Dunning, J. H. and Narula, R. (1996) Foreign Direct Investment and Governments: Catalysts for Economic Restructuring. London: Routledge

Dunning, J. H. and Philippe, G. (2008). International Business FDI, Location and Competitiveness. eds. Anderson. $U$ and Pederson $T$.

Dunning, J. H. (1981a). Explaining the International Direct Investment Position of Countries: Towards a Dynamic or Developmental Approach. Weltwirtschaftliches Archiv, 117(1), 3067. doi:10.1007/BF02696577 
Edwards, S. (1990). Capital flows, foreign direct investment, and debt-equity swaps in developing countries. NBER working paper no. 3497. Cambridge, MA: NBER.

Kohlhagen, S. W. (1977), "Exchange rate changes, profitability, and direct foreign investment", Southern Economic Journal, 44, 376-383.

Kyrkilis, D., Pantelidis, P. (2003). Macroeconomic Determinants of Foreign Direct Investment. International Journal of Social Economics,30(7), 827-836. doi: 10.1007/978-81-322-15363

Kueh, J. S. H., Puah, C. H., and Apoi, A. (2008). Outward FDI of Malaysia: An empirical examination from macroeconomic perspective. Economics Bulletin, 6(28), 1-11.

Kueh, J. S. H., Puah, C. H. and Wong, C. M. (2009). Bounds Estimation for Trade Openness and Government Expenditure Nexus of ASEAN-4 Countries. Economics, Management, and Financial Markets, 4(1), 103-112.

Hsiang, H. L., and Pitprapha, D. (2017). On the Determinants of Outward Foreign Direct Investment: Empirical Evidences from Thailand. International Research Journal of Finance and Economics ISSN 1450-2887

Michael, J. T. (1998). Patterns of Foreign Investment in the Third World in the Twentieth Century. Retrieved from http://www-personal.umd.umich.edu/ mtwomey/econhelp/FDI-Paper.pdf

Porter, M. (1990). The Competitive of Advantage of Nations. Free Press, New York: US Ruta, G. Determinants of FDI and its Motives in Central and Eastern European Countries. Retrieved from

http://lup.lub.lu.se/luur/download?func=downloadFile\&recordOId=1544335\&fileOld=1 647165

Ruta, G. (2010). Determinants of FDI and its Motives in Central and Eastern European Countries. Retrieved from https://pdfs.semanticscholar.org/5dd4/cd848eb02be7e28182817c291df334a30be5.pdf

Saad, R. M., Noor, A. H., and Nor, A. H. (2011). Home Countries' Determinants of Outward Foreign Direct Investment (OFDI) in Developing Economies: Malaysian Case. Vol. 2. 299-307. ISSN 2231-962x

Saad, R. M., Noor, A. H., and Nor, A. H. (2014). Developing Countries' Outward Investment: Push Factors for Malaysia. Procedia - Social and Behavioral Sciences, 130, 237-246. doi: 10.1016/j.sbspro.2014.04.028

Scaperlanda, A. E. and Mauer, L. J. (1973). The Impact of Controls on United States Direct Foreign Investment in the European Economic Community. Southern Economic Journal, 39(3), 419-423. doi: 10.2307/1056408

Sermcheep, S. (2013). Foreign Direct Investment and Economic Growth: The Case of Thailand's inward and outward FDI. (Master's degree), Chulalongkorn University, Thailand. 